\title{
Behavioral repertory of Trichodactylus panoplus (Crustacea: Trichodactylidae) under laboratory conditions
}

\author{
Bianca L. Zimmermann; Anaide W. Aued; Stela Machado; Daiara Manfio; \\ Laura P. Scarton \& Sandro Santos
}

\author{
Departamento de Biologia, Centro de Ciências Naturais e Exatas, Universidade Federal de Santa Maria. 97105-900 Santa \\ Maria, Rio Grande do Sul, Brasil. E-mail: bia.lais@gmail.com; ssantos@smail.ufsm.br
}

\begin{abstract}
This work describes the behavioral repertory of Trichodactylus panoplus von Martens, 1869, based on the animals' diel activity and the possible substrate preference under laboratory experiments. Three experimental replicates were carried out, each using six animals (three males and three females). There were four periods of observation a day, with a total of 864 observation sessions and 144 hours of experiments. A total of 15 behavioral acts divided into five categories were recorded: feeding, exploration of the environment, immobility, social interaction, and self-grooming. The obtained results suggest that $T$. panoplus has greater activity during the night $(p<0.05)$, yet without showing an activity peak. In addition, the acceptance of food does not depend on the photoperiod. There was a significant preference for gravel as the chosen substrate. The Morisita index indicates an aggregated distribution of these animals, confirming their preference for substrate with gravel. The increase in activity at night and the preference for substrate with gravel, which can be used to disguise these individuals, would be associated to some anti-predator strategies of these crabs against visually orientated predators.
\end{abstract}

KEY WORDS. Decapoda; diel activity; ethogram; substrate preference.

The freshwater crabs are grouped into the superfamilies Potamoidea, Pseudothelphusoidea, Gecarcinucoidea, and Portunoidea. This last group includes crabs from the Trichodactylidae family, which are important components of the aquatic biota in streams, rivers, lakes, and pools (MARTIN \& DAvis 2001).

Despite the ecological prominence of freshwater crabs, most of the studies about Brazilian benthic crustaceans are related to sea and estuarine species (Rocha \& Bueno 2004). Several causes contribute to this context, among them the presence of researchers near the seaside regions, the lack of comprehensive projects involving invertebrates in continental waters and, mainly, the lack of specialists (Melo 2003).

Trichodactylidae is represented by 51 species (Yeо et al. 2008), formed by small and median size exclusively freshwater crabs, which occur in Central and South America. There is little information about its biology and ecology. They are considered omnivorous and have direct larval development. They have nocturnal habits, remaining hidden in burrows, holes in submersed trunks, among the aquatic vegetation. or on rocks and trunks during the day (MagalHães 1999). There are three described trichodactylid species in the state of Rio Grande do Sul: Trichodactylus fluviatilis Latreile, 1828, T. kensley Rodriguez, 1992, and T. panoplus von Martens, 1869. The last one is widely distributed in the lakes along the coastal plain and in the Guaiba basin, occurring in tributaries of the Uruguay River as well
(MAGAlHÃEs 1999). Natural populations of T. panoplus are generally reduced, which makes field studies with this species difficult (Ayres-Peres et al. 2006).

Behavioral repertory studies and observations in the laboratory can contribute to a better understanding of the biology of populations for which field study is difficult (ALcock 1997, Del-Claro 2004). An ethogram is a formal description of the behavioral repertory of a species. It can be composed by a list of all behaviors presented by certain species or it can focus more specifically on functional classes of behavior (GRIER 1984).

There are relatively few studies on the behavioral repertory in decapod crustaceans. GRIFFIN $(1965,1968)$ described the basic repertory of the crab Heloecious cordiformis Milne Edwards, 1852 (Ocypodidae). Donaldson \& Adams (1989) generated an ethogram highlighting the copulatory behavior of the crab Chionoecetes bairdi Rathbun, 1924 (Majidae). STAmHuis et al. (1996) also provided an ethogram with the behaviors performed by Callianassa subterranea Montagu, 1808 (Thalassinidae). Kunz et al. (2006) described the behavioral activities of Palaemonetes pugio Holthuis, 1949 (Paleomonidae). BAIRD et al. (2006) presented an ethogram on the agonistic behavior of the freshwater lobster Cherax destructor Clark, 1936 (Parastacidae).

Due to the limited knowledge available about the trichodactylid crabs, it is fundamental to carry out studies which may give further information about these organisms. The aim of this work was to investigate, under laboratory conditions, 
the behavioral repertory of T. panoplus, as well as other aspects of behavioral biology of this species, such as the diel activity and substrate preference.

\section{MATERIAL AND METHODS}

Specimens of T. panoplus were collected in March, 2008 in a tributary of the Vacacai-Mirim river in Santa Maria, state

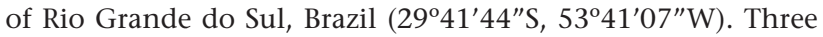
samples were obtained, one for each replicate of the study. Approximately ten individuals were caught in each sampling, yet only those which had all of their intact appendices and which did not present any signal of recent molting were included in the experiments. They were collected by hand and with the help of traps using bovine liver as bait. After being caught, the individuals were taken to the Carcinology Laboratory of Universidade Federal de Santa Maria and acclimated for five days in a common glass aquarium (50 x $25 \times 30 \mathrm{~cm})$ with continuous aeration. The animals were kept at around $23^{\circ} \mathrm{C}$ and a $12: 12 \mathrm{~h}$ (light: darkness) photoperiod. During the acclimatization, the animals were fed every two days with fish steak. Carapace width (between first anterior carapace spines) was measured in each specimen using a digital caliper to a 0.01 $\mathrm{mm}$ accuracy. Each animal was identified by means of small spots of different colors made on the cephalotorax, using fastdry paint, to enable their individual recognition.

The testing glass aquarium used in all the experiments had the same dimensions as the one used to acclimatize the animals. To carry out each experiment, the glass aquarium was filled with $20 \mathrm{~L}$ of filtered water and kept under continuous aeration.

The analyses of the behavioral repertory of $T$. panoplus was done based on three experimental replicates and in each one used different individuals, three males and three females, all of which in intermolt stage. The 1:1 sexual ratio was established based on the predominant pattern observed in other limnic crustaceans (Colpo et al. 2005, Gonçalves et al. 2006, Lima et al. 2006).

The observations in each replicate were carried out through the focal animal sampling method (AltMAnN 1974) in 10 minute sessions, followed by a resting period of five minutes. Each period of observation lasted for two hours, (without intervals) in which each animal was observed twice. There were four different periods of observation a day, two in the light photophase and two in dark photophase, covering each hour of the day along six days. The animals were fed with fish steak every two days and the food was released close to each animal and just during the period of observation. The feeding occurred in different periods to verify if the crustaceans accepted food every time it was offered. After this period, the food left was taken out of the aquarium.

During the observations, the frequency of the behaviors which had been qualified in previous observations for 30 hours was counted. Red light bulbs were used for nocturnal observa- tions, as they are widely used in experiments with crustaceans (TUrRa \& Denadai 2003).

During each period of observation, the temperature of the water and the air were measured and the period of light was from 07:00 AM to 07:00 PM. The observed behaviors were grouped into categories, and analyzed in relation to their frequency. A Student's $t$ test was used to test whether or not there was difference in the frequency of performing each behavioral act between males and females, and a $\chi^{2}$ test was used to assess whether the behavior presented by the animals are significantly associated with one of the photoperiods used in the experiment.

To test a possible preference for substrate, half of the bottom surface of the glass aquarium was covered with a $5 \mathrm{~cm}$ thick layer of sand (grain diameter $<1.0 \mathrm{~mm}$ ) and the other half with gravel (10-15 $\mathrm{mm}$ diameter), taken from the site where the animals were collected. These two kinds of substrate were selected because they represent the basic granulometric pattern of the sampling site. Based on the observations done every three hours, the average frequency of animals in each kind of sediment was compared using a Student's t test. All statistical tests were performed using Bioestat 3.0 (Ayres et al. 2003).

To confirm the data about preference for one or other kind of substrate, the testing glass aquarium was divided into 18 squares $(8.33 \times 8.33 \mathrm{~cm}$ each) and the location of all the specimens was recorded before the observation of each animal, verifying the squares occupied by them. The data were analyzed through the Morisita index of dispersion. This index is not related to the sampling average and indicates a random distribution when values are equal to one, a regular distribution when values are lower than one and a clustered distribution when values are higher than one (Morisita 1962). At the end of the observations, all the individuals were released back to their natural habitat.

\section{RESULTS}

The average size $(\mathrm{mm})$ of male and female used in the experiments was $21.86( \pm 2.21)$ and $17.82( \pm 1.35)$, respectively. The temperature ranged from $21.6^{\circ}$ to $25.6^{\circ} \mathrm{C}$ in the water, and from $22.2^{\circ}$ to $26.0^{\circ} \mathrm{C}$ in the air. A total of 864 observation sessions were conducted along 18 days, for a total of 144 hours. Fifteen behavioral acts were recorded, which were divided into five categories: feeding, exploration of the environment, immobility, social interaction, and self-grooming (Tab. I). The immobility category was the most common, corresponding to a frequency of $56.5 \%$ of the observations (Tab. II). There was no statistically significant difference in the time of the behaviors presented by males and females in all the categories observed.

The crabs were significantly more active $\left(\chi^{2}=17.21\right.$, $\mathrm{p}<0.05$ ) during the nocturnal period (dark photophase). Although statistically it is impossible to confirm an activity peak, it was possible to observe a greater mobility between 08:00 PM and 03:00 AM (Fig. 1). The crabs have eaten nearly every time the food was offered, regardless of the photoperiod. 


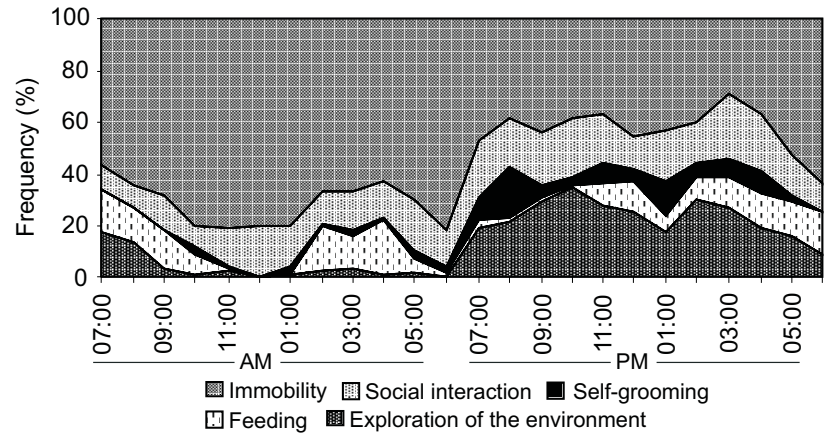

Figure 1. Trichodactylus panoplus: Diel pattern of activity under laboratory conditions.

There was a significant difference in relation to substrate preference, given that there was a frequency of $70.03 \%$ of animals remaining in the gravel as opposed to $29.97 \%$ of animals in the sand $(\mathrm{t}=-6.94, \mathrm{p}<0.05)$. The Morisita index was 1.58 , indicating a clustered or contagious distribution pattern.

\section{DISCUSSION}

The specimens of $T$. panoplus kept themselves more active during the period of less luminosity, indicating a preferentially nocturnal habit. Greater nocturnal activity has already been reported to other decapods. SoкоLowicz et al. (2007) observed that the anomuran Aegla longirostri Bond-Buckup, 1994 (Aeglidae) presents a greater activity at night, as well as the crabs Geocarcimus lateralis Freminville, 1835 (Geocarcinidae), Cardisoma guanhumi Latreille, 1825 (Gecarcinidae), Ocypode quadrata Fabricius, 1787 (Ocypodidae) and the semi-terrestrial anomuran Caenobita clypeatus Herbst, 1794 (Coenobitidae), whose activities occur preferably in the dark (PAlmer 1971). It was not possible to recognize a peak of activity in T. panoplus, however, it was possible to see a marked increase in mobility during the period from 8:00 PM to

Table I. Trichodactylus panoplus: description of behavioral acts under laboratory conditions.

\begin{tabular}{|c|c|}
\hline Behavioral categories & Behavioral acts \\
\hline \multicolumn{2}{|l|}{ Feeding } \\
\hline & $\begin{array}{l}\text { Stirring the substrate using the chelipods and taking them to the mouth: the specimens revolve the } \\
\text { substrate and carry its particles to the mouth. }\end{array}$ \\
\hline & $\begin{array}{l}\text { Still eating: the animal feed itself, moving the piece of food directly to its mouth or taking small pieces with the } \\
\text { chelipods and bringing them toward its mouth. }\end{array}$ \\
\hline & $\begin{array}{l}\text { Moving away from other animals with food: due to the arrival of some individual, the animal escapes from } \\
\text { the others taking its food with it. }\end{array}$ \\
\hline \multicolumn{2}{|c|}{ Exploration of the environment } \\
\hline & Walking: slow or fast motion on the substrate. \\
\hline & Revolving substrate: movement of pereiopods, leading to a motion of the substrate, either stones or sand. \\
\hline & Climbing the glass: trying to climb the glass aquarium. \\
\hline \multicolumn{2}{|l|}{ Immobility } \\
\hline & $\begin{array}{l}\text { Remaining buried: the individual total or partially buried in the substrate, with or without movement of the } \\
\text { appendices. }\end{array}$ \\
\hline & $\begin{array}{l}\text { Standing still, moving some of the appendices: individual still, moving antennae, antennules, ocular } \\
\text { peduncles, pereiopods and/or maxillipeds. }\end{array}$ \\
\hline & Standing completely still: the absence of any apparent movement. \\
\hline \multicolumn{2}{|l|}{ Social interaction } \\
\hline & $\begin{array}{l}\text { Friendly contact: one animal touches the other with its appendices, or even stays on the other, but there is no } \\
\text { signal of aggression, such as trying to hold with the chelipods or push the other crab. }\end{array}$ \\
\hline & $\begin{array}{l}\text { Agonistic contact: group of physical interactions among individuals represented mainly by interactions } \\
\text { involving the indiscriminate use of chelipods. }\end{array}$ \\
\hline \multicolumn{2}{|l|}{ Self-grooming } \\
\hline & $\begin{array}{l}\text { Movement of chelipods in direction to the open abdomen: the animal opens its abdomen, exposes the } \\
\text { pleopods and moves the pereiopods in their direction. }\end{array}$ \\
\hline & $\begin{array}{l}\text { Cleaning the antennules with the maxillipeds: the animal lowers the antennules and passes the maxillipeds } \\
\text { on them. }\end{array}$ \\
\hline & $\begin{array}{l}\text { Passing the chelipods on the cephalic appendices: chelipod movement through the antennae, antennules } \\
\text { and/or eye. }\end{array}$ \\
\hline & Passing chelipods on the pereiopods and maxillipeds: chelipod movement on the pereipods and maxillipeds. \\
\hline
\end{tabular}


Table II. Trichodactylus panoplus: average frequency of the behaviors observed in the three replicates of experiments.

\begin{tabular}{|c|c|c|}
\hline Behavioral categories & Behavioral acts & Frequency (\%) \\
\hline \multirow[t]{4}{*}{ Feeding } & & 8.69 \\
\hline & Stirring the substrate using the chelipods and taking them to the mouth & 1.02 \\
\hline & Still eating & 7.57 \\
\hline & Moving away from other animals with food & 0.10 \\
\hline \multicolumn{2}{|l|}{ Exploration of the environment } & 13.96 \\
\hline & Walking & 5.36 \\
\hline & Revolving substrate & 3.22 \\
\hline & Climbing the glass & 5.38 \\
\hline \multirow[t]{4}{*}{ Immobility } & & 56.50 \\
\hline & Remaining buried & 25.27 \\
\hline & Standing still, moving some of the appendices & 27.71 \\
\hline & Standing completely still & 3.52 \\
\hline \multirow[t]{3}{*}{ Social interaction } & & 16.31 \\
\hline & Friendly contact & 15.93 \\
\hline & Agonistic contact & 0.38 \\
\hline \multirow[t]{5}{*}{ Self-grooming } & & 4.54 \\
\hline & Movement of chelipods in direction to the open abdomen & 0.13 \\
\hline & Cleaning the antennules with the maxillipeds & 0.62 \\
\hline & Passing the chelipods on the cephalic appendices & 0.94 \\
\hline & Passing chelipods on the periopods and maxillipeds & 2.85 \\
\hline \multicolumn{2}{|l|}{ Total (5 behavioral categories) } & 100.00 \\
\hline \multicolumn{2}{|l|}{ Total (15 behavioral acts) } & 100.00 \\
\hline
\end{tabular}

3:00 AM, mainly due to substantial increase in the exploration of the environment. VALENTE \& EDWARDS (1955) have studied the activity rhythm of Trichodactylus petropolitans Goldi, 1886 crabs in the laboratory and showed that the movement start on average at 7:16 PM and ceases at 07:04 AM, being constant during the whole night. Besides, little activity was observed during the day. According to the authors, these data are similar to those obtained from observations in natural conditions, because it is possible to notice that animals stay immobile and hidden during the day and are active during the search for food at night. Such results are similar to those observed in T. panoplus, because the animals moved during the night and presented minimal movement during the day. This behavior may possibly represent a defense strategy against daytime predators. There were some reports about other crustaceans which live in environments similar to the $T$. panoplus, such as aeglids, or even Trichodactylus borellianus Nobili, 1896 (Trichodactylidae) and have predators with daytime habits, such as birds, mammals and fish (Burns 1972, Colurns et al. 2006).

During exploration of the environment, the animals run through the glass aquarium, apparently in search for food. However, its limited space may have constrained this activity, since the exploration of the environment was interrupted by the contact with the animals and the aquarium walls, and at this moment the trichodactylids tried to climb the glass. The same behavior was observed in the study carried out by Mineo et al. (2003) with the yellow scorpion Tityus serrulatus Lutz \& Mello, 1922 (Buthidae) and in crustaceans aeglids.

T. panoplus fed nearly every time food was offered, not only in its period of greater activity. Sokolowicz et al. (2007) observed the same response in the anomuran Aegla longirostri, which became active either in the light or dark phases when food was offered. REIGADA (2002) also observed that the crabs Callinectes ornatus Ordway, 1863 and Callinectes danae Smith, 1869 (Portunidae) had their activities altered when exposed to food, regardless of the photoperiod. Pontes \& Arruda (2005), who studied the shrimp Litopenaeus vannamei Boone, 1931 (Penaeidae) showed that food has acted as an inductor in the substrate exploration, either in the light or in the dark phase, making the shrimp more active in all times following its offer.

Most freshwater crabs are omnivorous and revolve the substrate searching for food, mainly taking in vegetal matter, but some are opportunist meat eaters, using either live or dead 
prey that they can find (Yeо et al. 2008). Usually, whenever individuals $T$. panoplus received food, they remained still, eating it. In some occasions, when other individuals were around and felt the presence of food, those which had the food went away carrying the piece of fish. In some moments there was even fight for this resource. In other moments, either with or without food in the aquarium, the individuals revolved the substrate with the chelipods and brought them toward their mouth, possibly catching small particles of food.

The most frequent behavioral category, immobility, is possibly a defense strategy which avoids the detection of the prey by visually oriented predators (EDMUNDs 1974). According to Coluins et al. (2006), who worked with the population dynamics of $T$. borellianus in Argentina, these individuals have an important trophic role since they are part of fish, amphibious, bird, and mammal diets. The social interaction category was the most common after the immobility and this remained relatively constant along the day. Agonistic contact occurred among individuals of the same sex as well as among individuals of opposite sex. Most of the disputes were related to food and place in the substrate. However, the animals spent more time to the friendly contact, possibly reflecting a tendency to aggregate.

When they were still or partially buried, the specimens of $T$. panoplus generally kept moving some appendices. The antennules were the most used structures since they constantly remained in movement, probably due to its sensorial functions. According to SteulLet et al. (2001) chemical perceptions are crucial to mediate behavioral patterns in many animals, and the antennules are the principal chemosensory organs of decapods crustaceans.

The self-grooming category was observed mainly at night. Besides the antennules, decapods crustaceans have chemioreceptors distributed into the mouthparts (SHELTON \& LAVARACK 1970), in the dactyls and propods of chelipods and in the pereiopods (Voigt \& Atema 1992, Gómes \& Atema 1996). Despite the cephalic region includes most of the sensorial organs, the moving appendices have received most of the attention regarding cleaning, because the trichodactylids spent more time for clean them. Keller et al. (2003), examined the role of some crab sensorial appendices in Callinectes sapidus Rathbun, 1896 (Portunidae) and concluded that the cephalic appendices make it possible for the animals to identify attractive smells. The signals noticed by the pereiopods allow the crabs to acquire information about spatial pattern of the chemical cues, which are important for orientation. The pleopods, limited to the abdominal region (which remains most of the time attached to the ventral part of these organisms) were also cleaned preferably during the night.

According to the Morisita index, T. panoplus presents a clustered distribution. Such distribution is probably related with the kind of substrate, given that the animals present significant preference for a specific substrate. That is, once there is preference for substrate with gravel, the crabs tend to group in these areas. In the natural environment this factor must also influence the distribution of these animals, once, during the collection, all animals sampled were next to areas with this kind of substrate. Nevertheless, it is necessary more studies to confirm this tendency, since others factors may be related to this choice. The preference for one specific substrate has been reported in other decapods (SÁNCHEZ 1997, RÖNNBÄCK et al. 2002, Quellette et al. 2003). It is possible that the T. panoplus preference may be an anti-predator strategy once on the gravel these animals became camuflaged (similar size and color). This relation of substrate and predation was showed by TALLMARK \& EVANS (1986) for the shrimp Crangon crangon Linnaeus, 1758 (Crangonidae). These authors have observed a significant reduction of predation when the animals were in their favorite substrate. Collins et al. (2006) also observed that T. borellianus chooses the substrate in order to avoid those with planktivorous fish predators. This way, T. panoplus would choose the substrate where it is more difficult for its predators to find them and, therefore, the individuals of this species would aggregate in this substrate, obtaining benefits with such behavior.

This study is precursor in relation to the behavioral biology of $T$. panoplus. In face the scarcity of works involving Trichodactylidae, we expect to have contributed to a better understanding of the behavioral biology of these animals, as well as to provide a basis comparisons with other freshwaters crustaceans.

\section{ACKNOWLEDGEMENTS}

We thank Luciane Ayres-Peres for her valuable criticisms and suggestions to this paper. We also thank to the reviewers for their suggestions, which were of great assistance to improve this work.

\section{LITERATURE CITED}

Alcock, J. 1997. Animal Behaviour, an Evolutionary Aproach. Sunderland, Sinauer Associates, 547p.

Altman, J. 1974. Observational study of behaviour: sampling methods. Behaviour 49: 227-265.

Ayres, M.; M. Ayres Jr; D.L. Ayres. \& A.S. Santos. 2003. BioEstat 3.0 Aplicações estatísticas nas áreas das ciências biológicas e médicas. Belém, Sociedade Civil de Mamirauá, 291p.

Ayres-Peres, L.; C.C. Sokolowicz \& S. Santos. 2006. Diversity and abundance of the benthic macrofauna in lotic environments from the central region of Rio Grande do Sul State, Brazil. Biota Neotropica 6 (3): 1-11.

Baird, H.P.; B.W. Patullo \& D.L. Macmillan. 2006. Reducing aggression between freshwater crayfish (Cherax destructor Clark: Decapoda, Parastacidae) by increasing habitat complexity. Aquaculture Research 37: 1419-1428.

Burns, J.W. 1972. The distribution and life history of south American freshwater crabs (Aegla) and their role in trout streams and lakes. Transactions of the American Fisheries Society 4: 595-607. 
Coluins, P.A.; F. Giri \& V. Williner. 2006. Population dynamics of Trichodactylus borellianus (Crustacea Decapoda Trichodactylidae) and interactions with the aquatic vegetation of the Paraná River (South America, Argentina). Annales de Limnologie - International Journal of Limnology 42 (1): 19-25.

Colpo, K.D.; L.O. Ribeiro \& S. SAnTos. 2005. Population biology of the freshwater anomuran Aegla longirostri (Aeglidae) from South Brazilian streams. Journal of Crustacean Biology 25 (3): 495-499.

Del-Claro, K. 2004. Comportamento Animal - uma introdução à ecologia comportamental. Jundiai, Livraria e Editora Conceito, 132p.

Donaldson, W.E. \& A.E. Adams. 1989. Ethogram of behavior with emphasis on mating for the tanner crab Chionoecetes bairdi Rathbun. Journal of Crustacean Biology 9 (1): 37-53.

EDMUNDS, M. 1974. Defense in animals: a survey of antipredatory defenses. Harlow, Longman, 357p.

Gómez, G. \& J. Aтемa. 1996. Temporal resolution in olfaction. I. Stimulus integration time of lobster chemoreceptor cells. The Journal of Experimental Biology 199: 1771-1779.

Gonçalves, R.S.; D.S. Castiglioni \& G. Bond-Buckup. 2006. Ecologia populacional de Aegla franciscana (Crustacea, Decapoda, Anomura) em São Francisco de Paula, RS, Brasil. Iheringia, Série Zoologia, 96 (1): 109-114.

Grier, J.W. 1984. Biology of Animal Behavior. St. Louis, Times Mirror, Mosby College Publishing, 693p.

Griffin, D.J.G. 1965. The behaviour of shore crabs. Australian Natural History 15: 87-91.

GRIFFIN, D.J.G. 1968. Social and maintenance behaviour in two Australian ocypodid crabs (Crustacea: Brachyura). Journal of the Zoological Society of London 156: 291-305.

Keller, T.A.; I. Powell \& M.J. Weissburg. 2003. Role of olfactory appendages in chemically mediated orientation of blue crabs. Marine Ecology - Progress Series 261: 217-231.

Kunz, A.K.; M. Ford \& O.J. Pung. 2006. Behavior of the grass shrimp Palaemonetes pugio and its response to the presence of the predatory fish Fundulus heteroclitus. American Midland Naturalist 155: 286-294.

Lima, G.V.; C.M. Silveira \& L.M.Y. Oshiro. 2006. Estrutura populacional dos camarões simpátricos Potimirim glabra e Potimirim potimirim (Crustacea, Decapoda, Atyidae) no rio Sahy, Rio de Janeiro, Brasil. Iheringia, Série Zoologia, 96 (1): 81-87.

Magalhães, C. 1999. Família Trichodactylidae (caranguejos braquiúros da água doce), p.486-490. In: L. BuCKuP \& G. BONDBuckup (Eds). Os Crustáceos do Rio Grande do Sul. Porto Alegre, Editora da Universidade Federal do Rio Grande do Sul, 514p.

Martin, J.W. \& G.E. Davis. 2001. An updated classification of the recent Crustacea. Los Angeles, Natural History Museum of Los Angeles County, Science Series 39, 124p.

Melo, G.A.S. 2003. Manual de identificação dos Crustacea Decapoda de água doce do Brasil. São Paulo, Ed. Loyola, 429 .
Mineo, M.F.; G.A. Franco-Assis \& C. Del-Claro. 2003. Repertório comportamental do escorpião amarelo Tityus serrulatus Lutz \& Mello 1922 (Scorpiones, Buthidae) em cativeiro. Revista Brasileira de Zoociências 5 (1): 23-31.

Morisita, M. 1962. I I $_{a}$ index, a measure of dispersion of individuals. Research in Population Ecology 4: 1-7.

Palmer, J.D. 1971. Comparative studies of circadian locomotory rhythms in four species of terrestrial crabs. American Midland Naturalist 85 (1): 97-107.

Pontes, C.S. \& M.F. ARruda. 2005. Comportamento de Litopenaeus vannamei (Boone) (Crustacea, Decapoda, Penaeidae) em função da oferta do alimento artificial nas fases clara e escura do período de 24 horas. Revista Brasileira de Zoologia 22 (3): 648-652.

Quellette, C.; A.D. Boghen; S.C. Courtenay \& A. ST-Hilaire. 2003. Infuence of peat substrate on the distribution and behaviour patterns of sand shrimp, Crangon septemspinosa, under experimental conditions. Journal of Applied Ichthyology 19: 359-365.

ReIgADA, A.L.D. 2002. Diel activity rhythm in Callinectes ornatus Ordway, 1863 and Callinectes danae Smith, 1869 (Brachyura, Portunidae) under laboratory conditions, p. 915-920. In: E. Escobar-Briones \& F. Alavarez (Eds). Modern Approaches to the Study of Crustacea. Norwell, Kluwer Academic, 381p.

RochA, S.S. \& S.L.S. Bueno. 2004. Crustáceos decápodes de água doce com ocorrência no Vale do Ribeira de Iguape e rios costeiros adjacentes, São Paulo, Brasil. Revista Brasileira de Zoologia 21 (4): 1001-1010.

Rönnbäck, P.; A. Macia; G. Almevist; L. Schultz \& M. Troell. 2002. Do penaeid shrimps have a preference for mangrove habitats? Distribution pattern analysis on Inhaca Island, Mozambique. Estuarine, Coastal and Shelf Science 55: 427-436.

SÁncheZ, A.J. 1997. Habitat preference of Penaeus duorarum Burkenroad (Crustacea: Decapoda) in a tropical coastal lagoon, southwest Gulf of Mexico. Journal of Experimental Marine Biology and Ecology 217: 107-117.

Shelton, R.G.J. \& M.S. Lavarack. 1970. Receptor hair structure and function in the lobster Homarus gammarus (L.). Journal of Experimental Marine Biology and Ecology 4: 201-210.

Sokolowicz, C.C.; L. Ayres-Peres \& S. Santos. 2007. Atividade nictimeral e tempo de digestão de Aegla longirostri (Crustacea, Decapoda, Anomura). Iheringia, Série Zoologia, 97 (3): 235-238. Stamhuis, E.J.; T. Reede-Dekker; Y. Van etten; J.J. Wiljes \& J.J. Videler. 1996. Behaviour and time of allocation of the burrowing shrimp Callianassa subterranea (Decapoda, Thalassinidae). Journal of Experimental Marine Biology and Ecology 204: 225-239.

Steullet, P.; O. Dudar; T. Flavus; M. Zhou \& C.D. Derby. 2001. Selective ablation of antennular sensilla on the Caribbean spiny lobster Panulirus argus suggests that dual antennular chemosensory pathways mediate odorant activation of searching and localization of food. The Journal of Experimental Biology 204: 4259-4269. 
Tallmark, B. \& S. Evans. 1986. Substrate-related differences in antipredator behaviour of two gobiid fish species and the brown shrimp, and their adaptive value. Marine Ecology Progress Series 29: 217-222.

Turra, A. \& M.R. Denadai. 2003. Daily activity of four tropical intertidal hermit crabs from southeastern Brazil. Brazilian Journal of Biology 63 (3): 537-544.

VALENTE, D. \& G.A. EDWARDS. 1955. The regulation of the activity rhythm of the crab Trichodactylus petropolitanus. Boletim da Faculdade de Filosofia, Ciências e Letras da Universi- dade de São Paulo 20: 5-12.

Voigt, R \& J. Aтемa. 1992. Tuning of chemoreceptor cells of the second antennae of the American lobster (Homarus americanus) with a comparison of four of its other chemoreceptor organs. Journal of Comparative Physiology A: Neuroethology, Sensory, Neural, and Behavioral Physiology 171: 673-683.

Yeo, D.C.J.; P.K.L. NG; N. Cumberlidge; C. Magalhães; S.R. Daniels \& M.R. Campos. 2008. Global diversity of crabs (Crustacea: Decapoda: Brachyura) in freshwater. Hydrobiologia 595: 275-286.

Submitted: 23.VII.2008; Accepted: 12.III.2009.

Editorial responsibility: Kleber del Claro 